N. Flynn bSc FFARCSI, D. P. O'Toole fFarCsI, E. Bourke MRCPI, K. O'Malley MD PhD FRCPE FRCPI, A. J. Cunningham FFARCSI FRCPC

\title{
The effect of local anaesthetics on epine- phrine absorption following rectal mucosal infiltration
}

This study was undertaken to investigate the effects of lidocaine and bupivacaine on epinephrine absorption following rectal mucosal infiltration, to assess the cardiovascular and metabolic effects of the absorbed epinephrine and to compare the systemic absorption of the local anaesthetics employed. Three groups of five greyhounds received $1.5 \mu \mathrm{g} \cdot \mathrm{kg}^{-1}$ of epinephrine 1:200,000 in lidocaine 0.5 per cent, bupivacaine 0.5 per cent or $0.9 \mathrm{per}$ cent saline. Plasma epinephrine, lidocaine, bupivacaine, lactate, glucose and potassium concentrations were measured at I, $2,5,10,15$ and 30 minutes following infilration. Plasma epinephrine concentrations were significantly higher in the lidocaine group at one and two minutes following infiltration. Plasma bupivacaine concentrations were significantly higher than plasma lidocaine concentrations throughout the study period. There were no significant differences in metabolic or biochemical indices within or between the three groups. A local vasodilatory action of lidocaine may enhance epinephrine absorption. Differences in hepatic uptake and rate of metabolism may explain the increased plasma bupivacaine measured. Lidocaine may be the local anaesthetic of choice for ano-rectal procedures, especially when large volumes of local anaesthetic are being infiltrated.

\section{Key words}

ANAESTHETICS, LOCAL: bupivacaine, lidocaine, absorption; SYMPATHETIC NERVOUS SYSTEM: pharmacology, epinephrine

From The Department of Anaesthesia and Clinical Pharmacology, Royal College of Surgeons in Ireland, Dublin, Ireland.

Presented, in part, at the Canadian Anaesthetists' Society Annual Meeting, Calgary, June 1987. This study was facilitated by funding from the Jervis Street Hospital Trust Fund.

Address Correspondence to: Dr. Anthony J. Cunningham, Royal College of Surgeons in Ireland, 123 St. Stephens Green, Dublin 2, Ireland.
As early as 1903 Braun demonstrated that the addition of epinephrine to local anaesthetic solutions greatly prolonged their duration of action.' Since then epinephrine has been used widely in clinical practice not only to prolong anaesthesia but also to provide optimal haemostasis and to minimize the systemic toxic effects of local anaesthetics. ${ }^{2,3}$ Significant haemodynamic and metabolic effects have been documented following epinephrinelocal anaesthetic infiltration. 4,5

Although epinephrine has been reported to delay the absorption of local anaesthetics, little information is available about the effect of local anaesthetics on epinephrine absorption. In a recent study Ueda et al. found that, in combination with lidocaine, the absorption of epinephrine is accelerated following cutaneous infiltration. A local vasodilatatory effect of lidocaine has been postulated as the mechanism. ${ }^{6}$

The objectives of this study were to investigate the effect of lidocaine and bupivacaine on the absorption of epinephrine following rectal mucosal infiltration: to study the systemic absorption of the local anaesthetics employed, and to assess the cardiovascular and metabolic effects of the absorbed epinephrine.

\section{Methods}

Employing a randomised cross-over trial design, three groups of five greyhounds weighing $23-33 \mathrm{~kg}$ were allocated to receive $1.5 \mu \mathrm{g} \cdot \mathrm{kg}^{-1}$ of epinephrine $1 /$ 200,000 in either $0.3 \mathrm{ml} \cdot \mathrm{kg}^{-1}$ normal saline, 0.5 per cent bupivacaine or 0.5 per cent lidocaine. Following induction of anaesthesia with thiopentone $20 \mathrm{mg} \cdot \mathrm{kg}^{-1} \mathrm{I}$. V., controlled ventilation to normocapnia was commenced. Anaesthesia was maintained with halothane 1.5 per cent in oxygen and the oesophageal temperature was maintained between $37-38^{\circ} \mathrm{C}$. Continuous ECG, end-tidal $\mathrm{CO}_{2}$ and direct intra-arterial blood pressure were monitored throughout. Following tracheal intubation and cannulation of the femoral artery, a ten-minute period was allowed to elapse to permit any sympathoadrenal response to wane. Baseline arterial blood samples were then taken 
for plasma epinephrine, glucose, potassium and lactate measurements. Forty per cent of the allocated epinephrine solution was then infiltrated beneath the perianal skin and each of the four quadrants of the rectal mucosa was injected with the remainder of the solution. The entire infiltration was carried out over a thirty-second period in each dog by the same investigator (D.O'T.). Further blood samples for measurement of plasma epinephrine, glucose, lactate potasium bupivacaine and lidocaine concentrations were taken at $1,2,5,10,15$ and 30 minutes following infiltration.

Blood samples for epinephrine estimations were immediately spun down in a cold centrifuge $\left(4^{\circ} \mathrm{C}\right)$ at $3000 \mathrm{rpm}$ and the supernatant was stored at $-70^{\circ} \mathrm{C}$ before determination of the plasma epinephrine concentrations. Following centrifugation of the blood samples for local anaesthetic estimations, the serum was removed and stored at $-20^{\circ} \mathrm{C}$ before analysis. The plasma epinephrine concentrations were measured by a high-pressure liquid chromatograph equipped with a $25 \times 4.6 \mathrm{~mm}$ reverse phase $\mathrm{C} 18$ column using a mobile phase of phosphate buffer, citric acid, EDTA, octane sulfonic acid, sodium salt and methanol which was helium degassed. The precision of the method was determined by repeated analysis of spiked serum samples, containing low concentrations of epinephrine $\left(50 \mathrm{pg} \cdot \mathrm{ml}^{-1}\right){ }^{7}$ In our laboratory, at concentrations of $10 \mathrm{pg} \cdot \mathrm{ml}^{-1}$, the method responds with a coefficient of variation of \pm 4.5 per cent.

The plasma bupivacaine and lidocaine concentrations were measured by a gas liquid chromatograph equipped with a six-foot column of 0.3 per cent $O V 17$ chromosorb W. H.P 100-120 mesh. The chromatograph was equipped with a nitrogen phosphate detector for lidocaine and a flame ionization detector for bupivacaine. The internal standards used were piriton and etidocaine for lidocaine and bupivacaine respectively. ${ }^{8}$ Coefficients of variation of the gas liquid chromatograph for bupivacaine were 2.28 per cent and 2.23 per cent for $0.9 \mu \mathrm{g} \cdot \mathrm{ml}^{-1}$ and $2.1 \mu \mathrm{g} \cdot \mathrm{ml}^{-1}$ samples respectively. Means and standard deviations were $0.92 \pm 0.021 \mu \mathrm{g} \cdot \mathrm{ml}^{-1}$ and $2.15 \pm$ $0.048 \mu \mathrm{g} \cdot \mathrm{ml}^{-1}$. The assay was sensitive to concentrations as low as $40 \mathrm{ng} \cdot \mathrm{ml}^{-1}$. For lidocaine the coefficients of variation were 2.59 per cent and 1.88 per cent for $0.8 \mu \mathrm{g} \cdot \mathrm{ml}^{-1}$ and $2 \mu \mathrm{g} \cdot \mathrm{ml}^{-1}$ samples respectively. Means and standard deviations were $0.85 \pm 0.022 \mu \mathrm{g} \cdot \mathrm{ml}^{-1}$ and $2.08 \pm 0.039 \mu \mathrm{g} \cdot \mathrm{ml}^{-1}$. The assay for lidocaine was sensitive to concentrations as low as $20 \mathrm{ng} \cdot \mathrm{ml}^{-1}$.

Plasma potassium was measured using a spectrum analyser with a direct ion selective electrode (Abbott Laboratories, North Chicago, Illinois). Plasma glucose concentrations were measured using a glucoroder with oxygen electrode (Analytical Instruments Co Tokyo, Japan) and plasma lactate concentrations were estimated by

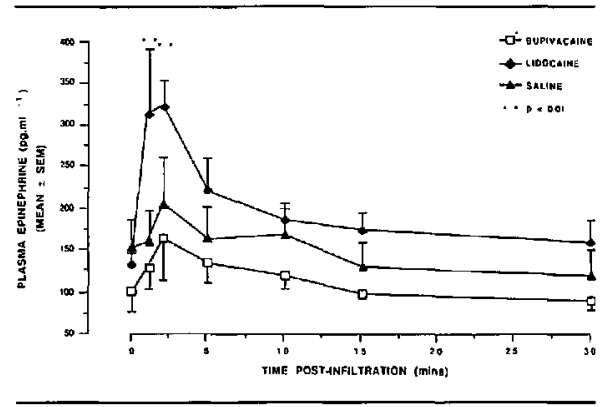

FIGURE 1 Plasma epinephrine concentrations following rectal mucosal infiltration. Data expressed as mean ( $\pm \mathrm{SEM}$ ).

a fluororimmuno-assay method (TDX system, Abbot Laboratories, North Chicago, Illinois).

The data were expressed as mean \pm SEM. A polynomial transformation was used to compare means at successive time points with baseline means as implemented in the SAS GLM statistical analytical technique. ${ }^{9} \mathrm{P}<0.05$ was considered to be statistically significant.

\section{Results}

Peak plasma epinephrine concentrations were recorded two minutes following rectal mucosal infiltration in all three groups. The epinephrine concentrations in the lidocaine group were significantly higher at one and two minutes after infiltration compared with the other two treatment groups (Figure 1). Both plasma bupivacaine and lidocaine peaked ten minutes after infiltration and thereafter tended to decrease towards baseline concentrations. Plasma bupivacaine concentrations remained significantly higher $(\mathrm{P}<0.01)$ than lidocaine concentrations throughout the study period (Figure 2).

Although there were no significant differences in metabolic indices either among or within the three treatment groups, both plasma glucose and lactate concentrations were elevated and peaked ten minutes after infiltration. The plasma potassium concentration remained unchanged throughout the study period (Figure 3).

Heart rate in the bupivacaine group was significantly reduced at 30 minutes following infiltration (Figure 4). There were no significant differences observed in the mean arterial and pulse pressures among the three groups.

\section{Discussion}

Several factors may influence the rate of absorption of local anaesthetic-epinephrine solutions - the vascularity of injection site, the rate of injection and the concentration 


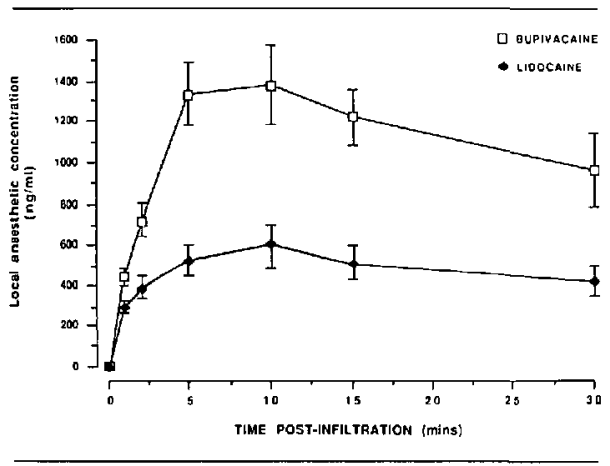

FIGURE 2 Plasma local anaesthetic concentrations after infiltration. Values expressed as mean ( \pm SEM).

and dosage of injectate. ${ }^{10} \mathrm{~A} 1.5-2.5$-fold increase in plasma epinephrine concentration was noted following rectal mucosal infiltration in this study. These values were considerably lower than data reported from other studies using different sites of injection. Up to 100-fold increases following scalp infiltrations and 18-fold increases follow-

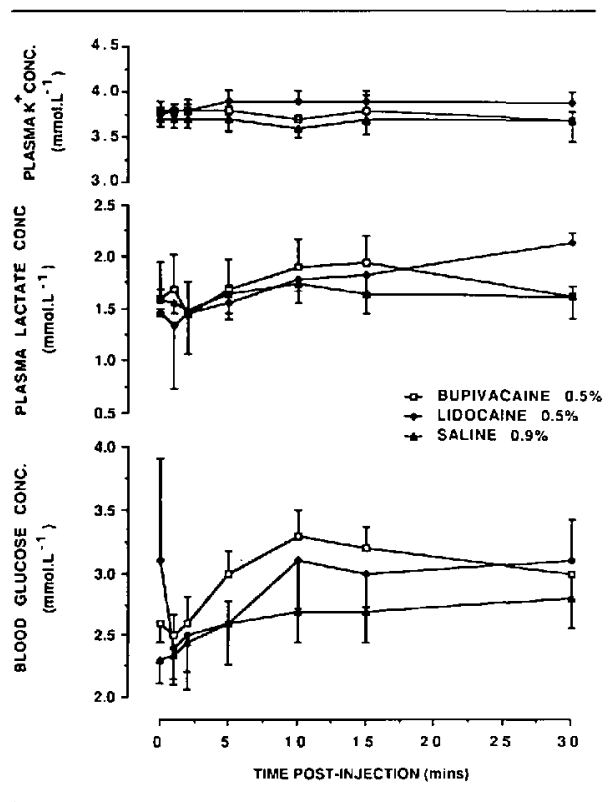

FIGURE 3 Plasma concentrations of potassium, lactate and glucose following infiltration. ing cervical mucosal infiltration have been reported. ${ }^{6,11}$ Barber et al. reported 15-fold increases in plasma epinephrine concentrations following peri-anal infiltration for haemorrhoidectomies in humans. ${ }^{12}$ Although the site of infiltration was similar to that used in the present study, the plasma epinephrine concentrations were higher. This may reflect the higher dosage used ( $2.9 \mathrm{mg} \cdot \mathrm{kg}^{-1}$ ) or interspecies variation.

This study confirms the enhanced epinephrine absorption reported in association with lidocaine 0.5 per cent. The pharmacological explanation for this increase in epinephrine absorption is, as yet, unknown. It has been suggested that a local vasodilatatory action of lidocaine may be responsible. ${ }^{6}$ However, bupivacaine 0.5 per cent intradermal administration has been reported to cause a more pronounced vasodilatation than lidocaine. ${ }^{13}$ Another explanation may be $\mathrm{pH}$ differences in the solutions injected. A recent study has shown that lidocaine's ability to increase epinephrine absorption was enhanced by a reduction in $\mathrm{pH}$ of the solution. ${ }^{14}$ This may be due to changes in tissue blood flow due to differences in $\mathrm{pH}$. A low $\mathrm{pH}$ causes local vasodilatation with an increase in tissue blood flow, thereby accelerating absorption of injected substances. The $\mathrm{pH}$ of bupivacaine and the lidocaine-epinephrine solutions used in this study were 3.7 and 3.4 respectively. There may be a critical $\mathrm{pH}$ at which maximal tissue blood flow occurs and therefore further studies are needed to elucidate the effect of $\mathrm{pH}$ on the vasodilatating activity of lidocaine.

An increase in circulating plasma epinephrine stimulates adenyl cyclase which is located on the internal surface of the plasma membrane of the target cell. This process accelerates the intracellular generation of a cyclic nucleotide which activates protein kinases. ${ }^{16}$ In the liver, activated phosphorylase kinases promote glycogen breakdown, resulting in an elevation of plasma glucose. In skeletal muscle, epinephrine promotes glycogen breakdown with the formation of lactic acid.

Exogenous epinephrine inhibits glucose - or glycogen - induced insulin secretion by stimulating alpha adrenoceptors on pancreatic islet beta cells. Epinephrine may also stimulate beta-adrenoceptors causing increased insulin secretion; however, this process is usually suppressed by simultaneous alpha adrenoceptor stimulation. ${ }^{17}$ The summation of these effects is enhanced glycogenolysis and gluconeogenesis, which would result in the increase of plasma glucose and lactate concentrations noted ten minutes after infiltration.

The effect of the systemic absorbtion of epinephrine on plasma potassium concentrations has been well documented. ${ }^{18} \mathrm{~A}$ transient increase followed by a marked prolonged decrease in plasma potassium is usually observed. The initial effect appears to be an alpha and beta 


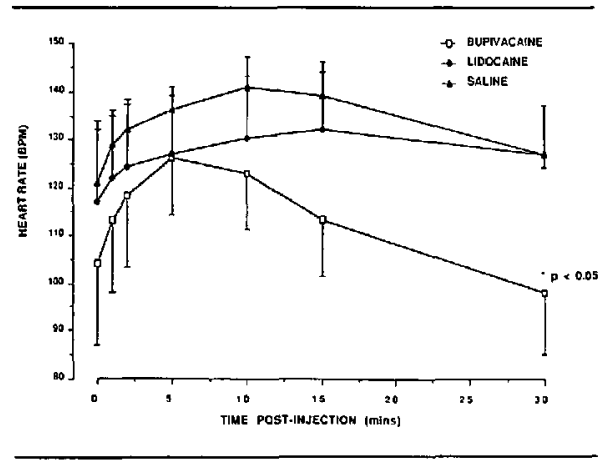

FIGURE 4 Changes in heart rate recorded after rectal mucosal infiltration.

adrenoceptor-mediated release of potassium from the liver while the subsequent decline may be due to a beta-adrenoceptor mediated influx of $\mathbf{K}^{+}$into liver and skeletal muscle celts. ${ }^{19,20}$ No significant changes in plasma potassium concentrations were observed in this study despite 1.5-2.5-fold increases in plasma epinephrine concentrations.

The plasma levels of both local anaesthetics peaked ten minutes after infiltration. Plasma bupivacaine levels were consistently higher than plasma lidocaine levels throughout the study period. Cardiotoxic effects of bupivacaine include decrease in heart rate and myocardial contractility, conduction disturbances, and arrythmias which may progress to ventricular fibrillation. ${ }^{21,22}$ In this study the increased plasma bupivacaine concentrations were associated with a significant decrease in heart rate which may reflect a direct depressant effect of bupivacaine on the sino-atrial node. ${ }^{23}$ Although the volumes of distribution of the two local anaesthetics are similar, bupivacaine is more highly protein bound, more lipid soluble, and undergoes a less rapid hepatic degradation than lidocaine. The differences in plasma concentrations of the two local anaesthetics observed may be explained, in part, by use of the rectal mucosa as the site of injection. A significant portion of rectal venous drainage communicates with the hepatic portal system. ${ }^{24}$ Up to 70 per cent of lidocaine may be metabolised due to the first pass effect, and is a possible explanation for the lower systemic bioavailability compared with bupivacaine. ${ }^{25}$

In clinical practice large volumes of local anaesthetics are often used for ano-rectal procedures. Our findings indicate that lidocaine may be the local anaesthetic of choice for such procedures. Because of its reduced systemic bioavailability after rectal mucosal infiltration, lidocaine may be less likely to cause systemic toxic effects. However, further clinical studies are needed to support this conclusion.

\section{References}

1 Braun $H$. Die lokal anastesie, ihre wirsenschaftlichen grundlagen und die praktische anwendung. Vierte Auflage, Verlay von Johann Ambrosius Baoth Leipzig (1903).

2 Braid DP, Scott $D B$. The systemic absorption of local analgesic drugs. Br J Anaesthesia 1965; 37: 394-401.

3 Covino BG, Vasallo $H G$. Local anaesthetics: mechanisms of action and clinical use. New York: Grune and Stralton 1975, Chapter 5, p. 45-7.

4 Cunningham AJ, Donnelly $M$, Baurke A, Murphy $F$. Cardiovascular and metabolic effects of cervical epinephrine infiltration. Obstet Gynecol 1985; 66: 93-8

5 Struthers $A D$, Reid $J L$, Whitesmith $R$, Rodgers JC. Effect of intravenous adrenaline on electrocardiogram, blood pressure and serum potassium. Br Heart J 1983; 49: 90-5.

6 Ueda W, Hirakawa M, Mori $K$. Acceleration of epinephrine absorption by lidocaine. Anesthesiology 1985; 63: 717-20.

7 Watson E. Liquid chromatography with electrochemical detection for plasma epinephrine and nor-epinephrine. Life Sci 1981; 28: 494-7.

8 Lesko $L J$, Ericson J. Simultaneous determinations of bupivacaine and 2-6-pipecoloxylidide in serum by gas liquid chromatography. J Chromatog 1980; 182: 226-31.

9 SAS Institute Inc. SAS Users guide, statistics. Version 5 Edition, Cary NC, SAS Institute Inc., 1985; 433-506.

10 Scott DB, Jebson PJR, Braid DP, Ortengren B, Frisch $P$. Factors affecting plasma levels of lignocaine and prilocaine. Br J Anaesth 1972; 44: 1040-8.

11 Low JM, Harvey JT, Cooper GM, Preudville WJ. Plasma concentrations of catecholamines following adrenaline infiltration during gynaecological surgery. Br J Anaesth 1984; 56: 849-52.

12 Barber WB, Smith LE, Zaloga GP et al. Haemodynamic and plasma catecholamine response to epinephrinecontaining peri-anal lidocaine anaesthesia. Anesth Analg 1985; 64: 924-8.

13 Aps $C$, Reynolds $F$. The effect of concentration on vasoactivity of bupivacaine and lignocaine. $\mathrm{Br} \mathrm{J}$ An aesth 1976; 48: 1171-4.

14 Ueda $M$, Hirakawa $M$, Mori $K$. Effect and interaction of $\mathrm{pH}$ and lidocaine on epinephrine absorption. Anesthesiology 1988; 68: 459-62.

15 Guyron $A C$. Textbook of Medical Physiology 6th Edn. W.B. Saunders Company 1980 p. 224.

16 Manger WM. Catecholamines in normal and abnormal cardiac function: adrenergic receptors and responses. Adv Cardiol 1982; 30: 17-25.

17 Porte D, Graber AL, Kujura T et al. The effect of 
epinephrine on immunoreactive insulin levels in man. $\mathbf{J}$ Clin Invest 1956; 45: 228-32.

18 Lim M, Linton RAF, Band DM. Continuous intravascular monitoring of epinephrine induced changes in plasma potassium. Anesthesiology 1982; 57: 272-5.

19 Jenkinson $D W$, Koller $K$. Interactions between effects of alpha and beta adrenoceptor agonists and adenine nucleotides on the memberane potential of cells in guinea pig liver slices. Br J Pharmacol 1977; 59: 163-7.

20 Vick RL, Todd EP, Lwdke DW. Epinephrine-induced hypokalaemia: relation to liver and skeletal muscle. J Pharmacol Exp. Ther 1972; 181: 139-45.

21 Tanz RD, Keskett T, Loehning RW, Fairfax CA. Comparative cardiotoxicity of bupivacaine and lidocaine in the isolated perfused mammalian heart. Anesth Analg 1984; 63; S49: 56.

22 Block A, Covino BG. Effect of local anaesthetics on cardiac conduction and contractility. Regional Anaesthesia $1981 ; 6: 55-61$.

23 Satoh $H$. Comparison of the chromotropic response to local anaesthetics (procaine, lidocaine, prilocaine, mepivacaine, and bupivacaine) of the canine sinus node in situ. Jpn J Pharmacol 1981; 31: 85-93.

24 Williams $P L$, Warwick $R$. Grey's Anatomy 36th Ed. Churchill Livingstone 1980; 6: 760 .

25 Mather LE, Tucker GT. Pharmacokinetics and biotransformation of local anaesthetics. In: International Anaesthesiology Clinics. Stanton Hicks (Ed.). 1978; pp. 23-53.

\section{Résumé}

Ce travail avait pour but de comparer la lidocaine et la bupivacaine injectées dans la muqueuse rectale quant à leur absorption et d̀ leur effet sur l'absorption de l'adrénaline. On voulait aussi mesurer l'impact cardiovasculaire et métabolique de l' adrénaline. Nous avons injecté $1.5 \mu \mathrm{g} \cdot \mathrm{kg}^{-1}$ d' adrénaline I:200,000 avec soit de la lidocaine 0.5 pour cent, soit de la bupivacaïne 0.5 pour cent ou du $\mathrm{NaCl} 0.9$ pour cent chez trois groupes de cinq lévriers. Les mesures sériées des concentrations sériques d'adrénaline, de lidocaïne, de bupivacaïne, de lactate, de glucose et de potassium étaient faites $1,2,5,10,15$ et 30 minutes après l' infiltraiton de la muqueuse. Nous avons mesuré des concentrations sériques d'adrénaline plus élevées dans le groupe lidocaine d̀ une et deux minutes et trouvé que les niveaux plasmatiques de bupivacaïne étaient systématiquement supérieurs à ceux de lidocaïne. Les variables métaboliques et biochimiques étaient semblables d'un groupe à l'autre. En vasodilatant, la lidocaïne peut faciliter l'absorption de l'adrénaline alors qu'une captation hépatique et un métabolisme plus faibles pourraient expliquer les niveaux plasmatiques elevés de bupivacaïne. La lidocaine est probablement le meilleur choix pour les infiltrations locales de grands volumes d'anesthésique lors de chirurgies ano-rectales. 